UDC 341.24(497.6)

DOI: $10.5937 / R K S P P 2002057 \mathrm{G}$

ALMIR GAGULA

ZLATAN MEŠKIĆ

\title{
TERMINATION OF THE CONTRACT UNDER FIDIC - THE PERSPECTIVE OF BOSNIA AND HERZEGOVINA
}

FIDIC Forms of Contract in recent years are often used for regulation of rights and obligations of the investors and the contractors on the construction projects in Bosnia and Herzegovina, in particular in construction of the highways, railways and dams. Majority of the projects is finalized without significant disputes between the parties. However, in certain cases disputes between the parties escalate in such magnitude that one of the parties decides to terminate the contract. Due to severity of the financial consequences of the termination, it is necessary to emphasise interplay between the Laws on Obligations in Bosnia and Herzegovina and FIDIC Forms. A careful approach to the issue of the termination could prevent complicated and expensive arbitral proceedings.

Key words: FIDIC, termination of the contract, good faith, abuse of rights, effects of termination

\section{INTRODUCTION}

Recent developments in the field of law of commercial contracts show the trend of pursuing the goal of harmonization of the rules of law in order to allow the parties to regulate their rights and obligations in an easier, more clear and

Dr. Almir Gagula, Assistant Professor, Faculty of Law, University of Zenica; Law office Gagula, e-mail:almir.gagula@gagula.ba.

Prof. Dr. Zlatan Meškić, Full Professor, College of Law, Prince Sultan University; Riyadh, e-mail:zmeskic@hotmail.com. 
more efficient manner. The construction law is not an exception from the trend. Erasing, or at least softening the borders in international trade is the goal of all stakeholders evident in the construction sector. Several driving forces are moving this process forward: international character of contractual relations calling for application of the rules of Private International $\mathrm{Law}^{1}$; different (legal) origin of the employer, the contractor and the engineer; significance of the economic interests involved.

FIDIC's Forms of Contract (FIDIC) that are aiming towards that goal, gained its part of international fame, especially in the Middle East, Southeast Asia and Eastern Europe. ${ }^{2}$ It is not our intent to describe the details of FIDIC, ${ }^{3}$ let alone explain its historical perspective and development route, it has already been done many times elsewhere. ${ }^{4}$ It is rather our intent to focus on specific issues of termination as one of the remedies granted to the employer and contractor under said forms. We shall also try to shed some light on the interplay between Bosnian law and FIDIC, when Bosnian law is agreed between the parties as the applicable law for their contract. ${ }^{5}$ We shall further discuss how FIDIC rules on termination fit in the context of Bosnian law and also limits of their applications. Bearing in mind that the core of the contract law in ex-Yugoslav republics is still SFRY's Law on Obligations 1978 (LOO), ${ }^{6}$ such an approach might not be only useful (strictly) for and from Bosnian law perspective.

Since FIDIC Forms are produced in different versions, covering different types of contractual relations within the construction industry, in order to narrow the scope of our article we shall specifically focus on the Conditions of Contract for Construction for Building and Engineering Works Designed by the Em-

1 The unification of the substantive law heads for the same goal. Cf. Zlatan Meškić, Slavko Đorđević, Međunarodno privatno pravo I - Opći dio, Sarajevo, 2016, 29.

2 Ellis Baker, Ben Mellors, Scott Chalmers, Anthony Lavers, FIDIC Contracts: Law and Practice, Informa Law from Routledge, 2009, 14-15.

3 Sometimes referred even as the dispositive law of international construction arbitration: Klee Lukas, International Construction Contract Law, 2nd edition, John Wiley \& Sons, 2018, 257.

4 Branko Vukmir, Kratki komentari FIDIC-ovih općih uvjeta građenja, RRiF-plus, Zagreb, 2013, 3-12.

5 Axel-Volkmar Jaeger, Götz-Sebastian Hök, FIDIC-A Guide for Practitioners, Berlin, Heidelberg, Springer, 2010, 66.

6 Službeni list Socijalističke Federativne Republike Jugoslavije, No. 29/1978, 39/1985, 45/1989 and 57/1989, Službeni list Republike Bosne i Hercegovine, No. 2/1992, 13/1993 and 13/1994, Službene novine Federacije Bosne i Hercegovine, No. 29/2003 and 42/2011, Službeni glasnik Republike Srpske, No. 7/1993, 3/1996, 37/2001, 39/2003 and 74/2004. 
ployer ( $1^{\text {st }}$ edition, 1999), more famous as the Red Book. To the extend necessary, we shall emphasize the specifics of $2^{\text {nd }}$ edition of Red Book (2017) - FIDIC GCC. ${ }^{7}$

\section{GENERAL REMEDIES OF THE EMPLOYER AND THE CONTRACTOR UNDER RED BOOK}

The remedies provided by the FIDIC Red Book can be divided into two groups: the Employer's remedies and the Contractor's remedies. In general, the Employer's remedies are dependable on certain breaches of the contract by the Contractor and related to the time-aspect of the project or the quality of the Works performed. In terms of time, the Contractor has a general duty to complete the Works within the Time for Completion. ${ }^{8}$ Should he fail to do so, the Employer shall be entitled to request agreed Delay Damages, as the remedy being somewhere in between the Common Law's Liquidated Damages ${ }^{9}$ and Contractual Penalty ${ }^{10}$ specific for the civil law legal systems. ${ }^{11}$ Likewise, should the Contractor perform the Works, but with some defects, the Employer shall have a right to reject the works ${ }^{12}$ or request remedial works. ${ }^{13}$ In case that the Works cannot be used for the intended purposes, the Employer has a right to request extension of Defect Notification Period. ${ }^{14}$ Should the Contractor fail to remedy the defects, the Employer is entitled to self-help ${ }^{15}$ or to reduction of the price. ${ }^{16}$ The Employer is also entitled to the costs suffered, at least in certain situations. ${ }^{17}$

On the other side of the spectrum, the Contractor is not left without own remedies for the Employer's breach. First and foremost, should the Employer fail to pay the price as agreed, the Contractor shall be entitled to the financing

7 Conditions of Contract for Construction, General Conditions, International Federation of Consulting Engineers, Second Edition, 2017.

8 A.V. Jaeger, G.S. Hök, op. cit., 205.

9 John Murdoch, Will Hughes, Construction Contracts - Law and Management, $4^{\text {th }}$ edition, Taylor \& Francis, 2008, 308.

10 For a Common law approach on matter of Contractual Penalties: Brian Eggleston, Liquidated Damages and Extensions of Time in Construction Contracts, Willey-Blackwell, 2009, 71 et seq.

11 The FIDIC Contracts Guide, FIDIC, First Edition, 2000, 177.

12 S-C 7.5 .

13 S-C 7.6.

14 S-C 11.3.

15 S-C 11.2.a.; E. Baker et al., op. cit., 423-424.

16 S-C 3.5 .

17 E.g. S-C 7.5, 7.6, 8.6, 9.2. 
charges, ${ }^{18}$ which might call for additional care of the parties in terms of possible application of certain mandatory rules from the applicable law. ${ }^{19}$ Aside from the financing charges which are intended to be clear and easily established, more important Contractor's remedies are related to the time and the costs generated by the events in responsibility of the Employer. In case of various situations where the Employer is direct cause of prolongation, or at least contractually responsible for its effects, the Contractor shall be entitled to a remedy in a form of Extension of Time for Completion (EoT) ${ }^{20}$ Second most important remedy linked to the Employer's responsibilities, is entitlement for additional money payment. ${ }^{21}$ However, most radical and thus highly important remedy granted to both parties in certain situations is entitlement to the termination of the contract. Those entitlements are to some extent different in terms of conditions and application, thus deserve separate observation.

\section{TERMINATION BY THE EMPLOYER}

General regime of the Employer's entitlement to the termination is laid down in Clause 15 of FIDIC Forms. ${ }^{22}$ Unlike the Contractor, the Employer is entitled to two types of termination: termination for cause and termination for convenience. ${ }^{23}$

The termination for cause is based on the Contractor's breach of the obligations from the Contract. FIDIC sets out a termination regime in a way that entitles the Employer to request rectification of the failure in the fulfilment of any Contractor's obligations from the Contract, with the obligation to grant the Contractor an additional but reasonable time to comply with its obligations. The duty of the Employer to grant an additional reasonable time is inherently linked to the Good Faith principle, that in and of itself declines the possibility of general termi-

18 S-C 14.8 .

19 Compounding is for example forbidden in Bosnian law pursuant to Art. 277 LOO.

20 Julian Bailey, Construction Law, Routledge, 2011, 835. Without any intention to list all the scenarios where the Contractor is entitled to such remedy, which list would extend beyond the limits of this article, we shall mention the following: delayed drawings or instructions (S-C 1.9) or access to the site (S-C 2.1), unforeseen physical conditions (S-C 4.12), delay caused by the authorities (S-C 8.5) etc.

${ }^{21}$ E.g. in case of delays caused by the delayed drawings, instructions, access to the site, unforeseen physical conditions, delay in partial taking over, force majeure etc.

22 Nael G. Bunni, The FIDIC Forms of Contract, $4^{\text {th }}$ ed., Blackwell Publishing, 2005, 548-549.

23 As is the case in Bosnian law pursuant to Art. 629 LOO. 
nation of the agreement for insignificant failures, ${ }^{24}$ but rather calls for preservation of the contract (in favorem contractus). Significance of the Contractor's failures to perform shall be assessed against the facts of the case. The purpose of a notice is to allow the Contractor to remedy the failure, and while doing so it must not be prevented or hindered from performing his obligation. ${ }^{25}$

Apart from (non)rectification of the failures in the fulfilment of the Contractor's obligation, the entitlement of the Employer to terminate the contract is further linked to specific events, giving rise to the Employer's right to terminate the Contract. Looking at the FIDIC Forms, it seems that FIDIC provides rather detailed list of the situations giving rise to the entitlement for the Contract termination, instead of providing for a general clause as used in Bosnian law. ${ }^{26}$ The Employer under FIDIC Forms has the right to terminate the Contract in the situations listed in the following table.

\begin{tabular}{|c|c|c|}
\hline Grounds for Termination & RB99 Clauses & RB17 Clauses \\
\hline $\begin{array}{l}\text { Failed to provide Performance Security or to } \\
\text { comply with the Notice to Correct }\end{array}$ & $\begin{array}{c}\text { 15.2.a. } \\
4.2 \\
15.1\end{array}$ & $\begin{array}{c}\text { 15.2.a. } \\
\text { 15.2.e. } \\
\text { 3.7 (Agreement or } \\
\text { Determination) } \\
21.4 \text { (DAAB's decision) }\end{array}$ \\
\hline $\begin{array}{l}\text { Abandoned the Works or plainly demonstrat- } \\
\text { ed intention not to continue its performance }\end{array}$ & 15.2.b. & 15.2.b. \\
\hline $\begin{array}{l}\text { Without excuses fails to proceed with the } \\
\text { Works or to comply with a notice related to } \\
\text { Rejection and Remedial Work }\end{array}$ & $\begin{array}{c}15.2 . c . \\
8 \\
7.5,7.6\end{array}$ & $\begin{array}{l}\text { 15.2.c. } \\
15.2 . \mathrm{d}\end{array}$ \\
\hline $\begin{array}{l}\text { Subcontracts the whole Works or assigns the } \\
\text { contract without Employer's consent }\end{array}$ & 15.2.d. & 15.2.f. \\
\hline $\begin{array}{l}\text { The Contractor becomes bankrupt, insolvent } \\
\text { or similar }\end{array}$ & 15.2.e. & 15.2.g. \\
\hline $\begin{array}{c}\text { The Contractor becomes involved in bribery } \\
\text { or similar acts }\end{array}$ & 15.2.f. & 15.2.h. \\
\hline
\end{tabular}

24 Antaios Compania Naviera SA v SalenRederierna AB [1985] AC 191 at 201D.

25 Obrascon Huarte Lain SA v Her Majesty's Attorney General for Gibraltar [2014] EWHC 1028 (TCC) (16 April 2014), para. 324.

26 Art. 124 LOO. 
List of the grounds for the termination is not exhausted with the above, but the right exists also in other situations, e.g. in case of failure to pass the Test on Completion, to Remedy the Defects, in case of Force Majeure etc. ${ }^{27}$

In case of the events or circumstances listed in S-C 15.2, the Employer shall firstly have an obligation to issue the (first) notice to the Contractor, with a 14 days deadline for compliance with the Notice. This notice prior termination should not be confused with the general notice to correct defined by S-C 15.1, where in case of general failure to comply with the obligation from the Contract, the Employer has an obligation to issue first Notice to Correct, followed by notice prior termination under S-C 15.2. The Notice to Correct within additional 14 days is a general rule, subject to certain exceptions (S-C15.2.2). First, in case of bankruptcy, insolvency or similar proceedings against the Contractor, the Employer shall not have an obligation to issue Notice to Correct but will have a direct right to terminate (Notice of Termination). Bankruptcy or similar proceedings against the Contractor are showing that the Contractor is not able to perform its obligations under the contract (i.e. to pay workforce, sub-contractors, head office costs, machine rentals, materials etc.), as such endangering the whole Works. Second, in case of the acts of bribery or similar.

FIDIC Forms 99 did not make a specific linguistical distinction between two or even three possible notices related to the Employer's entitlement for termination. Even though careful reading of the Clause 15 leaves no doubt, there might be some confusion as to how many notices the Employer should submit in order to achieve a lawful termination under FIDIC. It should be clear that the Notice to Correct within a reasonable time (S-C15.1) should not be confused with 14 days' notice prior termination (S-C15.2) and final Notice of Termination. This means that even in case of unresolved Notice to Correct (S-C15.1), the Employer has an obligation to issue additional Notice with 14 days deadline (S-C15.2), before finally terminating the contract with (final) Notice of Termination. Notice to Correct therefore is not per se a Notice from S-C 15.2.

When comparing Bosnian law general termination regime with FIDIC, there are some similarities. Under Bosnian law, the creditor wishing to terminate the contract must issue a notice granting additional reasonable time for fulfilment, ${ }^{28}$ and if that notice is of no avail, another notice of termination shall be necessary. ${ }^{29}$ However, the notice shall not be necessary for the transactions with

27 E. Baker et al., op. cit., 438.

28 Art. 126 LOO.

29 Art. 130 LOO. 
fixed deadline, where the contract shall be terminated ex lege. ${ }^{30}$ In contrast, FIDIC Forms do not recognize automatic termination of the contract. FIDIC Forms 17 made a distinction with rather clear wording. Firstly, there is a clear and detailed provision of S-C 15.1 describing in details the content of the Notice to Correct. ${ }^{31}$ Unlike in FIDIC Forms 99, the Notice to Correct now must not only describe the Contractor's failure, but also state exact provisions of the Contract it relates to, and also the reasonable time for remedying the failure, that shall not result with extension of the Time to Complete.

Secondly, the Notice prior termination (under S-C 15.2) must also describe itself as a notice under S-C 15.2.1, in order to avoid any misunderstanding ${ }^{32}$ whether this is just a Notice prior termination or Notice of termination itself.

Thirdly, now the Notice of Termination is described in clear words as the "... second notice".

Even though this approach made a distinction clearer, more could be achieved by naming the notices as: Notice to Correct, Notice prior Termination and Notice of Termination. That would erase, to the best possible extent, any confusion that might arise between the parties, and consequently prevent rather expensive disputes over the nature and effect of specific notice. Should the Contractor fail to comply with the Notice prior Termination (or in case of bankruptcy and bribery immediately), the Employer shall be entitled to terminate the contract with a Notice of Termination. Consequences raised by the termination of the Contract are rather serious. The Contractor shall leave or be expelled from the site and deliver the Goods, Contractor's documents, or the design documents (S-C 15.2.3 and 15.2.4).

After the notice of termination becomes effective, the Engineer has an important obligation to settle the outcome of the termination..$^{33}$ The Engineer shall have to perform the valuation after the termination and issue its determination with the goal to either agree, or in absence of the agreement between the parties, determine the value of the Works, Goods and any Contractor's documents, as well as any sum due to the Contractor. Immediately thereafter the Employer shall be entitled to submit its claims pursuant to S-C 2.5 and to withhold any fur-

30 Art. 125.1 LOO.

31 This was also suggested to be an understanding of the advisable application of FIDIC Forms 1999 as well, e.g. Michael D. Robinson, A Contractor's Guide to the FIDIC Conditions of Contract, Wiley-Blackwell, 2011, 52; E. Baker et al., op. cit., 405.

32 In order to avoid any disputes, the same request of self-describing is highly advisable for Notice of Claim from Clause 20.

33 S-C 15.3. 
ther payment until all the costs for remaining works, the delay damages and other costs have been established. It shall also be entitled to recover any extra costs of completing the works. After the Employer recovers its losses, damages, and extra costs, it shall pay any balance due to the Contractor. ${ }^{34}$

Another type of the termination by the Employer is the termination for convenience under S-C 15.5. The Employer is entitled to terminate the Contract at any time, with 28 days' notice, provided that the Works shall not be executed by the Employer or another contractor. In this specific case the Contractor shall be entitled to the payments pursuant to S-C 19.5. The same option is given to the Employer under Bosnian law, where the right to terminate the contract is also granted only to the Employer. ${ }^{35}$

\section{TERMINATION BY THE CONTRACTOR}

The Contractor is not entitled to terminate the Contract for convenience, but only for cause. In case of the Employer's failure to fulfil obligations on its part, the Contractor shall have a right to utilise two remedies. The Contractor shall be able to suspend the Works if the Employer fails two issue the Interim Payment Certificate or pay the amounts due to the Contractor. ${ }^{36}$ Such a suspension shall be without prejudice to (other) Contractor's rights, including financing charges, ${ }^{37}$ termination, ${ }^{38}$ EoT or any $\operatorname{costs}^{39}$ and reasonable profit incurred as a result of such suspension. The Contractor shall also be, under certain conditions, entitled to terminate the Contract. ${ }^{40}$ The list of scenarios under which the Contractor shall be able to terminate ${ }^{41}$ is a bit more detailed than in case of the Employer's termination entitlement. ${ }^{42}$

34 S-C 15.4.

35 Art. 629 LOO.

36 S-C 16.1.

37 S-C 14.8.

38 S-C 16.2.

39 For more details on potential heads of claims see Andrew Burr, Delay and Disruption in Construction Contracts, $5^{\text {th }}$ edition, Informa Law, 2016, 884 et seq.

40 Some authors describe Contractor's rights as relatively limited. James Bramen, Leith Ben Ammar, "The Guide to Construction Arbitration", Global Arbitration Review, Law Business Research Ltd, 2017, 70.

41 Željko Popović, Odštetni zahtevi u građevinarstvu, Građevinska knjiga, Beograd, 2009, 224.

42 William Godwin, International Construction Contracts - A Handbook with commentary on the FIDIC design-build forms, John Wiley \& Sons, 2013, 67. 
A. Gagula, Z. Meškić: Termination of the Contract under FIDIC ...

\begin{tabular}{|c|c|c|}
\hline Grounds for Termination & RB 99 Clauses & RB 17 Clauses \\
\hline $\begin{array}{c}\text { No action of Employer within } 42 \text { days after Notice } \\
\text { of Suspension }\end{array}$ & 16.1 & 16.1 \\
\hline Failure to issue Payment Certificate & $14.6,14.13$ & $14.6,14.13$ \\
\hline Failure to pay amounts due to Contractor & 14.7 & 14.7 \\
\hline $\begin{array}{c}\text { The Employer substantially fails to perform his } \\
\text { obligations under Contract }\end{array}$ & 16.2.d & 16.2.1.e. \\
\hline $\begin{array}{l}\text { The Employer fails to comply with Contract } \\
\text { Agreement or Assignment }\end{array}$ & $1.6,1.7$ & $1.6,1.7$ \\
\hline $\begin{array}{l}\text { The Employer fails to comply with binding } \\
\text { Agreement, Determination or DAAB's decision }\end{array}$ & & $3.7,21.4$ \\
\hline $\begin{array}{l}\text { The Contractor does not receive Notice to } \\
\text { Commence within } 84 \text { days after Letter of Acceptance }\end{array}$ & & 8.1 \\
\hline $\begin{array}{l}\text { A prolonged suspension affects the whole of the } \\
\text { Works }\end{array}$ & 8.11 & 8.12 \\
\hline The Employer becomes bankrupt, insolvent or similar & 16.2.g. & 16.2.1.i. \\
\hline $\begin{array}{l}\text { The Employer becomes involved in bribery } \\
\text { or similar acts }\end{array}$ & & 16.2.1.j. \\
\hline
\end{tabular}

In terms of the procedure, the Contractor may terminate the Contract with 14 days' notice, except in case of a prolonged suspension affecting the works and bankruptcy of the Employer, where no such notice is necessary. The termination of the Contract shall come into effect after the Contractor issues the Notice of Termination. This essentially generates a need for two notices (one prior to termination and notice of termination itself). ${ }^{43}$ As is the case with Termination by Employer, FIDIC Forms 17 did provide some clarity in terms of the procedure, essentially emphasising that there are two notices, explicitly naming the notice of termination as "second Notice". 44 Effects of the Contractor's termination are similar to the effects of the Employer's termination. The Contractor shall have an obligation to cease all further works, hand over the Documents, Plan, Material

$43 \mathrm{~S}-\mathrm{C}$ 16.2. On this part this regime is distinct to the termination under dispositive rules of LOO in Bosnia and Herzegovina, where after the creditor grants additional time for fulfilment, and the debtor fails to rectify, the contract is terminated without further need for any notice, i.e. ex lege, Art. 126 LOO.

${ }^{44}$ S-C 16.2.2. 
and other works paid, remove all the goods from the site and finally leave it. ${ }^{45}$ In terms of monetary consequences, the Employer shall thereafter have an obligation to return the Performance Security, pay all the amounts due as well as any loss or profit or other loss and damage sustained by the Contractor as a result of the Contractor's termination. ${ }^{46}$

\section{FIDIC AND THE APPLICABLE LAW(S)}

Even though it is intention of the FIDIC to cover the issues of construction contracts in details, importance of the national law cannot be ignored. FIDIC Forms define that the contract between the parties shall first and foremost be regulated by the law of the country the parties agreed on in the Appendix to Tender. ${ }^{47}$ The definition of the "laws" accepted by FIDIC Forms includes all national (or state) legislation, statutes, ordinances and other laws, and regulations and bylaws of any legally constituted public authority. ${ }^{48}$ FIDIC emphasises the importance of the obligation of the parties to comply with the laws in several S-C: 1.13 (Compliance with laws), 2.2 (Permits, Licenses or Approvals), 4.18 (Protection of the Environment), 6.4 (Labour Laws), 13.7 (Adjustment for Changes in Legislation) etc. This naturally raises the issue of interplay between FIDIC Forms and the law of the country agreed between the parties, as well as mandatory laws in the countries where the Works are performed, that shall have to be applied irrespective of the agreement of the parties regarding the applicable law. ${ }^{49}$ The two shall be the same in most cases, i.e. the law of the country of Works, ${ }^{50}$ but different scenario is not excluded. That said, the parties to the Contract will have to deal with mandatory laws on one side, and applicable law on the other. This interference will have significant influence on the rights and obligations of the parties. When dealing with the mandatory rules, the parties' choice of law or even the parties' agreement, will not be able to supersede the mandatory rules. ${ }^{51}$ Which rules of

45 S-C 16.3.

46 S-C 16.4 .

47 S-C 1.4 .

48 S-C 1.1.6.5.

49 Pierre Mayer, "Mandatory Rules of Law in International Arbitration", Arbitration International, 1986, 274-275.

50 Charles Molineaux, "Moving Toward a Lex Mercatoria - A Lex Constructionis", Journal of International Arbitration, Vol. 14, No. 1, 1997, 55 et seq.

51 Klaus Peter Berger, “The Lex Mercatoria Doctrine and the UNIDROIT Principles of International Commercial Contracts", Law and Policy in International Business, Vol. 28, 943, 1997, 961. 
the laws fall into this category is a matter for a conflict of law analysis, ${ }^{52}$ being eased by the reference of FIDIC Forms to the issue of laws, which are mostly linked to the laws of the country in which the site is located. ${ }^{53}$ Certainly, the importance of the mandatory rules of the applicable law agreed between the parties is not lesser. Many of the mandatory rules consisted in applicable law shall have a direct influence on the application of the contract terms..$^{54}$

The provisions of the applicable law that falls into the category of ius dispositivum lie on the other side of the spectrum. They apply in the case that the parties did not agree on different terms and therefore allow the parties to accommodate their needs. ${ }^{55}$ And precisely there, relationship between Bosnian dispositive rules and FIDIC shows the advantage of FIDIC's detailed regulation of the termination against general regime of the termination under LOO in Bosnia and Herzegovina.

\section{SPECIFICS OF LAW ON OBLIGATION IN BOSNIA AND HERZEGOVINA AND INFLUENCE ON RIGHT ON TERMINATION UNDER THE FIDIC FORMS}

In this section we shall focus on the interplay between LOO in Bosnia and Herzegovina and FIDIC Red Book, and and at least endeavor to establish that: a) dispositive nature of Bosnian law enables and goes hand-in-hand with detailed regulation of termination under FIDIC, b) Bosnian rules regarding insignificant non-fulfilment as a corrective measure for the termination are not directly applicable to FIDIC Forms of Contract, c) other less harmful remedies are not an obstacle for the termination under FIDIC Forms of Contract, d) principles of good faith and prohibition of abuse of rights apply to the termination under FIDIC as well.

Termination of the contract under the Bosnian law is one of the methods of the cessation of the contractual obligations. ${ }^{56}$ As such, it is complementary with

52 Linda Silberman, Franco Ferrari, "Getting to the Law Applicable to the Merits in International Arbitration and the Consequences of Getting it Wrong", Conflict of Laws in International Commercial Arbitration, (eds. Franco Ferrari, Stefan Kröll), European Law Publishers, Munich, 2011, 257-324.

53 S-C 1.1.6.2.

${ }^{54}$ Davor Babić, Fran Pecilarić, "Validity of the Time Bar under FIDIC Sub-Clause 20.1 in Croatian Law", Construction Arbitration in Central and Eastern Europe, Contemporary Issues, Wolters Kluwer, 2020, 138.

55 Abedin Bikić, Obligaciono pravo - Opći dio, 3. izm. i dop. izd., Sarajevo, 2013, 20. $2000,154$.

56 Bogdan Loza, Obligaciono pravo - Opšti dio, 4. dop. i izm. izd., Beograd, Službeni glasnik, 
universal methods of the termination of the contract ${ }^{57}$ in the modern legal systems. Irrespective of the different conditions for the termination, different methods, and various legal effects, it is a common ground that the termination of the contract is universally accepted in the Contract Law. One of the many specifics of the FIDIC contracts is that the arbitration is a first option for final dispute resolution, after passing through preceding stages of FIDIC's multi-tier dispute resolution clause. ${ }^{58}$ This is precisely the reason for lack of FIDIC related court case law in Bosnia and Herzegovina. This in and of itself raises various questions regarding application of FIDIC in conjunction with Bosnian law as the applicable law. One of the key issues is the termination of the Contract.

Starting point is that provisions of the contract law in Bosnia and Herzegovina are indeed mostly of dispositive nature..$^{59}$ Those rules are equally applicable ex lege as the rules of mandatory nature. ${ }^{60}$ Should the parties agree on different terms of the contract, dispositive rules shall not apply and vice versa. ${ }^{61}$ The authorities are in unison ${ }^{62}$ regarding dispositive nature of the rules of LOO regulating the termination and its consequences, ${ }^{63}$ as well as the case law. ${ }^{64}$ Dispositive nature of the provisions of LOO regarding the termination opened the possibility for the parties to agree on the specifics of the termination: conditions, way of termination and its consequences. This is precisely what FIDIC Forms establish with their provisions in Clauses 15 and 16. Both of these clauses, from the perspective of Bosnian law, are to be considered as the termination based on the will

57 Živomir Đorđević, Vladimir Stanković, Obligaciono pravo - Opšti deo, Beograd, Naučna knjiga, 1987, 308.

58 Clause 20.

59 Dragoljub Stojanović, Komentar Zakona o obligacionim odnosima, Knjiga prva, Pravni fakultet Kragujevac i Kulturni centar Gornji Milanovac, 1980, 165.

60 However, the issue of Iura novit Curia in an international arbitration should be carefully observed in relation to the provisions and the approach of Lex arbitri. E.g. French courts established strict and consistent approach to the issue of Iura novit curia in international arbitration, requesting from the arbitral tribunal not to exceed the boundaries of the pleadings of the parties. Cf. Marta Viegas de Freitas Monteiro, Jura Novit Curia in International Commercial Arbitration, Helsingfors universitet, 2013, 70-73.

61 Zoran Rašović, Građansko pravo, Podgorica, 2006, 33-34.

62 Almir Gagula, "Usklađenost instituta raskida ugovora u pravu BiH sa Načelima evropskog ugovornog prava”, Pravna misao, Sarajevo, br. 7-8, 2010, 13.

63 Vesna Klajn-Tatić, Docnja prodavca sa predajom stvari, Beograd, 1983, 111. Cf. Prof. Loza on parties' autonomy regarding lex comissoria, B. Loza, op. cit., 156.

${ }^{64}$ Legal position of Cantonal Court in Sarajevo No. 1/2003 and Gž-2712/05 dated 4.10.2010; Supreme Court of FBiH No. 14453/2015 dated 29.12.2015. 
of the parties (clausula iritatoria). FIDIC's termination provision establishes the right to unilateral termination and defines conditions that must be fulfilled in order to terminate the Contract. In addition, FIDIC defines legal consequences of the termination in detail. This leads to conclusion that FIDIC's provision on unilateral termination defines in detail main issues related to the termination: right to terminate, mode of termination and its consequences. This is in line with the principle of freedom of contract provided for in Art. $10 \mathrm{LOO}$ and does not breach mandatory rules defined by provisions of either LOO or other laws in Bosnia and Herzegovina.

Thereby, FIDIC Forms defining their own rules for contract termination ${ }^{65}$ completely exclude application of the provisions of Art. 124-132 LOO which establish the general regime of termination in Bosnian law. This is applicable for both the Employer's and the Contractor's termination. This general position does not exclude an application of the provisions of LOO that are applicable to all agreements in general. This in particular includes the application of general principles of LOO to Clauses 15 and 16 of FIDIC Forms.

It is noteworthy that such approach would also exclude the possibility to use the provisions of Art. 124-132 Law on Obligation for the benefit of FIDIC's system of termination. One of the Articles that is often referred to by the party trying to supress the effects of Clauses 15 or 16 is provision of Art. 131 LOO that prevents the termination of the agreement due to the nonfulfillment of slight, minor part of the other party's obligation. The case law in Bosnia and Herzegovina in general holds that Art. $131 \mathrm{LOO}$ also falls into the category of ius dispositivum, thus enabling the parties to define different or completely exclude its application. ${ }^{66}$ Even though detailed provisions on termination in FIDIC exclude application of Art. $131 \mathrm{LOO},{ }^{67}$ it is important to emphasise the approach of the LOO to this issue. LOO did not set a concrete criterion for application of Art. 131 LOO. It is rather left for the judge or the arbitrators to assess if non-fulfilment in exact factual matrix falls into the category of insignificant non-fulfilment. As a criterion for such assessment it is suggested that one might investigate if the non-fulfilled obligation is the main or secondary obligation; whether the obligation is divisible or not; or even if (partial) non-fulfilment of the obligation endan-

65 E. Baker et al., op. cit., 448, para. 8.197 and 496, para. 8.322.

${ }^{66}$ Decision of the Cantonal Court in Sarajevo, Bilten sudske prakse Kantonalnog suda u Sarajevu, No. 1/2003, 16.

67 Supreme Court FBiH No. 14453/2015 dated 29.12.2015. 
gers the main goal of the agreement. ${ }^{68}$ The main criteria is that partial fulfilment of the obligation should correspond with legitimate expectations of the parties, ${ }^{69}$ and this in turn calls for determination of the intent of the parties at the moment of the contract's conclusion, and also estimation how partial fulfilment is contrary to such expectations of the parties. In doing so, one must take into account that provisions of Clauses 15 and 16 are precisely aimed at resolving this issue. Consequently, in order to terminate the contract, conditions from these clauses must be met, irrespective of assessment if this falls into the scope of Art. 131 LOO. Simply put, Art. 131 LOO shall not be applied and cannot be used as a corrective measure against application of Clauses 15 and 16 FIDIC.

The right to termination exists regardless of the fact if the creditor has at its disposal another, less harmful remedy that would be less detrimental to the interests of the other party, i.e. debtor. Although this argument is not developed in scholarly work, it is not rare, at least from the personal experience of the authors of this article. In short, the argument is framed in a way that the employer, protected by security in a form of the Advance Payment Guarantee (S-C 14.2) or the Performance Security (S-C 4.2), should be prevented from terminating the agreement even if conditions from Clauses 15 and 16 are met. Irrespective of lack of logic of such argument (the Employer always has the Performance Guarantee), there is no exact legal ground for such an approach. Clearly, FIDIC Forms do not provide any clause that can be used as a basis for such an argument. As far as LOO is concerned, when conditions provided for in Art. 124 et seq. LOO are met, the creditor is able to choose one of the remedies that it has at its disposal. It shall be either entitled to request fulfilment of the obligation or termination, and in any way the creditor shall be entitled to pursue its claim for damages suffered as a result of delayed fulfilment of debtor's obligation. ${ }^{70}$ To that extent, existence of the various guarantees in favour of the creditor is not an obstacle for the termination of the agreement, so it remains within the boundaries of sole discretion of the creditor to terminate the agreement or not. Sub-Clause 15.2 explicitly emphasises that the decision of the Employer to terminate the Contract shall not prejudice any other rights the Employer has under the Contract or otherwise (i.e. under applicable law). The same is provided for the Contractor's termination in S-C 16.2.

68 Boris Vizner, Komentar Zakona o obveznim odnosima, Knjiga 1, Zagreb, 1978, 524.

69 A. Bikić, op. cit., 207.

70 Art. 124 LOO. 
It is therefore understandable that the Contractor or the Employer are not under the obligation to choose a remedy that is less detrimental for the other party.

Above said does not exclude the application of the general principles of LOO. The starting point for observation of the interplay between general principles on one side, and FIDIC's provisions on the termination on the other, should be the principle of freedom of contract. Pursuant to Art. 10 LOO the parties are indeed free to determine their contractual relations as they wish, provided that they stay within the limits defined by the Constitution, mandatory rules and good practice. Freedom of contract is precisely the source of contractual regulation of unilateral termination. ${ }^{71}$ On the other hand, this principle finds its boundaries within the scope of mandatory rules of Bosnian legal system. As far as businessto-business relations are observed, there are no exact provisions of the law limiting the freedom of the parties regarding the right to unilateral termination. However, widely recognized ${ }^{72}$ principles of good faith ${ }^{73}$ under Art. 12 and prohibition of abuse of rights under Art. $13 \mathrm{LOO}$ are corrective factors to the freedom of contract and the usage of the rights. One might also argue that existence of these corrective instruments in Bosnian law is not surprising, ${ }^{74}$ due to the transnational public policy that the principle of good faith is a part of. ${ }^{75}$ Likewise, Lex Construction, as Lex Mercatoria in general, relies on the good faith principle in terms of facilitation of performance of the contract and disclosure of the information relevant for the contract. ${ }^{76}$

Under Art. $12 \mathrm{LOO}$ the parties have the obligation to respect the principle of good faith while entering into the obligations and when exercising the rights arising from those obligations. Its purpose is to be used for the interpretation of other legal provisions, ${ }^{77}$ but also the rights and obligations of the parties, whereas it enables determination of ancillary obligations which were not agreed between 2006, 69 .

71 A. Bikić, op. cit., 206; B. Vizner, op. cit., 507; Đorđe Nikolić, Obligaciono pravo, Beograd,

72 Klaus Peter Berger, The Creeping Codification of the Lex Mercatoria, The Hague, London, Boston, 1999, 167.

73 Arbitration CAS 2002/O/410 The Gibraltar Football Association (GFA)/Union des Associations Européennes de Football (UEFA), para. 11.

74 ICSID Award, AMCO Asia Corp. et al. v. The Republic of Indonesia et al., YCA 1985, para. 47.

75 ICC Partial Award No. 6474 of 1992, YCA 2000, para. 36.

76 C. Molineaux, op. cit., 64.

77 ICC Award No. 8908, ICC Bull. 10/No. 2 (1999), 86. 
the parties, but are necessary for fulfilment of their obligations and good faith principle. The good faith principle also includes prohibition of contradictory behaviour ${ }^{78}$ (venire contra factum proprium) ${ }^{79}$ known as estoppel by representation in common law countries or as the principle of consistency in French law. ${ }^{80}$

The good faith principle interferes with the principle of prohibition of abuse of rights ${ }^{81}$ established in Art. 13 LOO. Within the wording used, LOO expressly prohibits only usage of the rights against the goal that was basis for establishment of such right. However, the prohibition should be observed a bit more extensively. In general, the right of one person is not unlimited, but it finds its boundaries against the rights of other parties or public interest. ${ }^{82}$ The main consequence of the breach of this prohibition is liability for the damages caused. ${ }^{83}$ An application of these two limitation principles should be careful. The court or the tribunal should firstly establish the source of the obligation in order to apply the principles on concrete, not abstract obligation of the parties. ${ }^{84}$

Bearing that in mind, approach to the provisions of Clauses 15 and 16 should be that they fall under the scope of ius dispositivum from perspective of Bosnian law, and as such, their application cannot be generally considered as a breach of principles of good faith and/or prohibition of abuse of rights. The facts of each case should be observed in order to make a conclusion that the usage of either clause 15 or 16 by the Employer or the Contractor should be prohibited. It is not enough to make an arbitrary approach and consider mere usage of clear clausulae iritatoriae as being contrary to these, indeed important principles.

78 Principles of European Contract Law, (eds. Ole Lando, Hugh Beale), Kluwer Law International, $1^{\text {st }}$ edition, 1999,114 .

79 D. Stojanović, op. cit., 107 et seq.; ICC Interim Award to Case No. 10671, Clunet 2006, 1417, para. 53; ICC Second Preliminary Award Made In Case No. 1512, YCA 1980, 175 (also published in: ASA Bull. 1992, at 505 et seq.).

80 Philippe Fouchard, Emmanuel Gaillard, Berthold Goldman on International Commercial Arbitration (eds. Emmanuel Gaillard, John Savage), The Hague, 1999, 820, para. 1462; Rolf Herber, Beate Czerwenka, Internationales Kaufrecht, Munich, 1991, 50.

81 Prohibition of Abuse of Rights is also principle of European Community law. EuGH C-321/05, Hans Markus Kofoed v. Skatteministeriet, 5. July 2007, para. 38.

82 A. Bikić, op. cit., 55.

83 B. Vizner, op. cit., 80-82.

${ }^{84}$ Decision of District Court in Banja Luka, No. Gž 14611/2014 dated 16.09.2015. 


\section{Dr ALMIR GAGULA}

docent Pravnog fakulteta Univerziteta u Zenici

Advokatski ured Gagula, Sarajevo

Dr ZLATAN MEŠKIĆ

redovni profesor Univerziteta u Zenici,

profesor na College of Law, Prince Sultan University

\section{RASKID UGOVORA PREMA FIDIC-u \\ - PERSPEKTIVA BOSNE I HERCEGOVINE}

Rezime

FIDIC Opšti uslovi su u posljednjim godinama često korišteni za uređenje prava i obaveza između investitora i izvođača na građevinskim projektima u Bosni i Hercegovini, posebno ugovorima o građenju autoputeva, željeznica i brana. Većina projekata je završena bez značajnih sporova između strana. Međutim, u određenim slučajevima sporovi između stranaka eskaliraju do te mjere da jedna od strana odluči da raskine ugovor. S obzirom na ozbiljnost finansijskih posljedica raskida, nužno je naglasiti uzajamno dejstvo između Zakona o obligacionim odnosima u Bosni i Hercegovini i FIDIC Opštih uslova. Pažljiv pristup pitanju raskida ugovora bi mogao spriječiti komplikovane i skupe arbitražne postupke. raskida

Ključne riječi: FIDIC, raskid ugovora, savjesnost i poštenje, zloupotreba prava, posljedice

Bibliography

Babić D., Pecilarić F., "Validity of the Time Bar under FIDIC Sub-Clause 20.1 in Croatian Law", Construction Arbitration in Central and Eastern Europe, Contemporary Issues, Wolters Kluwer, 2020.

Bailey J., Construction Law, Routledge, 2011.

Baker E., Mellors B., Chalmers S., Lavers A., FIDIC Contracts: Law and Practice, Informa Law from Routledge, 2009.

Berger K.P., “The Lex Mercatoria Doctrine and the UNIDROIT Principles of International Commercial Contracts), Law and Policy in International Business, Vol. 28, 943, 1997.

Berger K.P., The Creeping Codification of the Lex Mercatoria, The Hague, London, Boston, 1999.

Bikić A., Obligaciono pravo - Opći dio, 3. izm. i dop. izd., Sarajevo, 2013.

Bramen J., Ammar L.B., “The Guide to Construction Arbitration”, Global Arbitration Review, Law Business Research Ltd, 2017.

Bunni N.G., The FIDIC Forms of Contract, $4^{\text {th }}$ ed., Blackwell Publishing, 2005.

Burr A., Delay and Disruption in Construction Contracts, $5^{\text {th }}$ edition, Informa Law, 2016. 
de Freitas Monteiro M.V., Jura Novit Curia in International Commercial Arbitration, Helsingforsuniversitet, 2013.

Đorđević Ž., Stanković V., Obligaciono pravo - Opšti deo, Beograd, Naučna knjiga, 1987.

Eggleston B., Liquidated Damages and Extensions of Time in Construction Contracts, Willey-Blackwell, 2009.

Fouchard P., Gaillard E., Berthold Goldman on International Commercial Arbitration, (eds. Emmanuel Gaillard, John Savage), The Hague, 1999.

Gagula A., "Usklađenost instituta raskida ugovora u pravu BiH sa Načelima evropskog ugovornog prava”, Pravna misao, Sarajevo, br. 7-8, 2010.

Godwin W., International Construction Contracts - A Handbook with commentary on the FIDIC design-build forms, John Wiley \& Sons, 2013.

Herber R., Czerwenka B., Internationales Kaufrecht, Munich, 1991.

Jaeger A.V., Hök G.S., FIDIC - A Guide for Practitioners, Berlin, Springer, Heidelberg, 2010.

Klajn-Tatić V., Docnja prodavca sa predajom stvari, Beograd, 1983.

Loza B., Obligaciono pravo - Opšti dio, 4. dop. i izm. izd., Beograd, Službeni glasnik, 2000.

Lukas K., International Construction Contract Law, 2nd ed., John Wiley \& Sons, 2018.

Mayer P., "Mandatory Rules of Law in International Arbitration", Arbitration International, 1986.

Meškić Z., Đorđević S., Međunarodno privatno pravo I - Opći dio, Sarajevo, 2016.

Molineaux C., "Moving Toward a Lex Mercatoria - A Lex Constructionis", Journal of International Arbitration, Vol. 14, No. 1, 1997.

Murdoch J., Hughes W., Construction Contracts - Law and Management, $4^{\text {th }}$ ed., Taylor \& Francis, 2008.

Nikolić Đ., Obligaciono pravo, Beograd, 2006.

Popović Ž., Odštetni zahtevi u građevinarstvu, Građevinska knjiga, Beograd, 2009.

Principles of European Contract Law, (eds. Lando O., Beale H), Kluwer Law International, 1st edition, 1999.

Rašović Z., Građansko pravo, Podgorica, 2006.

Robinson M.D., A Contractor's Guide to the FIDIC Conditions of Contract, Wiley-Blackwell, 2011.

Silberman L., Ferrari F., "Getting to the Law Applicable to the Merits in International Arbitration and the Consequences of Getting it Wrong", Conflict of Laws in International Commercial Arbitration, (eds. Franco Ferrari, Stefan Kröll), European Law Publishers, Munich, 2011.

Stojanović D., Komentar Zakona o obligacionim odnosima, Knjiga prva, Pravni fakultet Kragujevac i Kulturni centar Gornji Milanovac, 1980. 
A. Gagula, Z. Meškić: Termination of the Contract under FIDIC ...

Vieras de Freitas Monteiro, M., Jura Novit Curia in International Commercial Arbitration, Helsingfors universitet, 2013.

Vizner B., Komentar Zakona o obveznim odnosima, Knjiga 1, Zagreb, 1978.

Vukmir B., Kratki komentari FIDIC-ovih općih uvjeta građenja, RRiF-plus, Zagreb, 2013.

Article history

Received: 05.10.2020.

Accepted: 14.10.2020.

ORIGINAL SCIENTIFIC PAPER 